\title{
Rethinking Management of the 21st Century: An Approach to Contemporary Business Education
}

\section{Repensar la gestión del siglo XXI: un enfoque de la educación empresarial contemporánea}

\author{
Dmitry V. Kuzin \\ dvkuzin@inbox.ru \\ https://orcid.org/0000-0002-5223-0719 \\ Doctor of Economics, Professor, Lomonosov Moscow State University, Moscow, \\ Russian Federation
}

Recibido: 09/05/21

Aceptado: $12 / 07 / 21$

\begin{abstract}
This paper is addressing the issues of modern management thinking which became one of the most critical tasks in contemporary business education. Such thinking must reflect all major changes and challenges in science, technology, economy, politics, culture, and society which took place within the first two decades of the 21 st century and especially now in the times of pandemic crisis. It is very important not only in terms of analysis but also as an explanation of the patterns of business and management behavior. It became the topic of serious scientific debate of the most prominent business researchers and consultants. The purpose of the article is to develop the methodological approach for further research of modern management and suggest the conceptual model which could structure the analysis of contemporary business reality. The author suggests the conceptual model for further research which could explain the essence of new management revolution. Such open model could be added and interpreted and is already applied in different educational programs in Russia.
\end{abstract}

Keywords: management, paradigms, thinking, changes, education.

\section{Resumen}

Una de las tareas críticas en la educación empresarial contemporánea es el desarrollo del nuevo pensamiento de gestión que refleja todos los cambios y desafíos importantes en ciencia, tecnología, economía, política, cultura y sociedad que tuvieron lugar durante las dos primeras décadas del siglo XXI. Todos estos cambios significan un serio cambio de paradigma en las formas y modelos de pensamiento y comportamiento, en normas y estándares, en comunicaciones y conducta empresarial, en valores e incluso en 
significados de nuestra actividad y vida. El lugar y el papel del liderazgo y la gestión en las organizaciones de hoy están cambiando, así como sus competencias, capacidades, habilidades prácticas esenciales y conocimientos para prosperar en la economía global del siglo XXI impulsada por el conocimiento. Si no entendemos realmente la complejidad y la imprevisibilidad del mundo en el que vivimos, el impacto social de las nuevas tecnologías emergentes y revolucionarias, la esencia y la velocidad del cambio, y nuestro destino real, es muy difícil mantenerse eficaz, antifrágil. y sobrevivir en un entorno hipercompetitivo y dinámico. Varios de los principales pensadores empresariales del siglo XXI han dedicado gran parte de su investigación a estos temas preguntándose sobre los cambios y el futuro de la gestión. Se espera que este artículo contribuya a esta discusión de manera metodológica, abordando varias nociones y conceptos básicos esenciales para comprender la realidad empresarial contemporánea.

Palabras clave: paradigma gerencial, revolución gerencial, pensamiento gerencial, tendencias modernas, complejidad, cambios, educación empresarial.

\section{Introduction}

The 21st century has changed the foundations of modern societies, business and organizations. This has led to a borderless "flat" world (Friedman, 2007). We are facing the serious paradigm shift in the ways and models of thinking and behavior, in norms and standards, in communications and business conduct, in values and even in meanings of our activity and life. The place and the role of leadership and management in today's organizations are also changing as well as their competences, capabilities, essential practical skills and knowledge to thrive in the knowledge-driven 21st century global economy. If we don't really understand the complexity and unpredictability of the modern world we live in, the social impact of new emerging and breakthrough technologies, the essence and speed of change, and our real destination, it's very difficult to stay effective, "anti-fragile" (Taleb, 2012) and survive in a hyper competitive and dynamic environment.

All these changes are impressive with big challenges, new threats and tremendous opportunities. We have to deal with the post-modern reality with plurality, diversity, nonsimilarity, uniqueness, difference, etc. Globalization and Fourth Industrial Revolution have transformed technology, society and the way of our life, global economy, markets and competition, industries and organizations, communications, and business models. It also has shrunken product, company's and strategy life cycles adding high speed of changes (Andersson et al, 2018; Goleman, 1996). Digital transformation is on the way with completely new principles and approaches to business, leadership and management (Kane et al, 2018; Schwab, 2016).

Today's people as employees, customers, suppliers, investors, creators, team and community members are different. Most of the workers in modern organizations are the "digital natives" (those who grew up with the emerging technologies) as opposed to the "digital immigrants" (the majority populated business and public organizations and born 
before the advent of modern technologies and learning to use them) (Prensky, 2001). They care about different things, they are better educated and informed, their expectations are changing and rising, they need personal attention, desire for more flexible, self-directed forms of work that allow better work-life balance, they live and operate in multicultural environment. Client centricity and consumer-driven activity are one of the mail pillars of current digital transformation, enhancing human potential and creativity are the key issues.

The nature and patterns of work have changed and became fundamentally incompatible with hierarchical command and control. We are evidencing dramatic increase in knowledge work; service work displaces manufacturing; digital technologies and virtual businesses transform work and create new jobs which are replacing many traditional; long gone are the days of spending the whole of your career at one company; up-skilling and re-skilling will become even more important than before (Oswald, A., Müller, W., 2017).

New assets (knowledge, intelligence, talents, etc.) became the key competitive advantages. New values of creativity, innovations, relationships, quality, social responsibility, and others are the drivers of changes and further development. Globalization, diversity, and ethics have forced management of all types of organizations to totally rethink their approaches to operations, human resources and interactions. Because of such paradigm shift, organizations are now more responsive to both their external and internal environments

The purpose of the article is to develop the methodological approach for further research of modern management and suggest the conceptual model which could structure the analysis of contemporary business reality. Such a model could also be used in the education process as, on the one side, the structured and clear tool of research, and, on the other side, as an adaptive model open for additions and interpretations.

\section{Literature Review}

A number of leading business thinkers of the 21st century have devoted much of their research to the topics mentioned above asking about the future of management. The paradigm shift is the key ingredient in understanding change (Barker, 1993). It means fundamentally altering the way of thinking - of stable beliefs, assumptions, generalizations, behavior and practice, of the way things are done. Paradigms are "rarely analyzed, rarely studied, rarely challenged-indeed rarely even made explicit." (Drucker, 1998).

As soon as many authors have started talking about management paradigm shift at the beginning of the 21 st century management the theoretical research has focused on new management mind-set. Management thinking became one of the key notions frequently mentioned in contemporary business theoretical papers, articles and books. Different types of management thinking - systems, creative, innovation, design, outstripping, multi- 
dimensional, value-based, global, strategic, client centricity, digital and other - are widely explored and analyzed. One thing is doubtless - real today's leaders and winners have different thinking.

Speaking about management paradigm shift different authors suggest different names of such transformation - "management DNA M2.0" (Hamel, 2000), "agile M3.0" (Apello, 2011; Oswald and Müller, 2017), "radical management" (Denning, 2010), "conscious management" (Mackey and Sisodia, 2014), "freedom-based management" (Nobles and Staley, 2010), etc. Whatever it is called, it is radically different from the dominant management mindset of most top managers, from the practices usually advocated by leading consulting firms, and from the majority of management practices taught in today's universities and business schools (Denning, 2013). Actually each of these concepts suggest multi-shifts (multi-changes) in values, in organizations, in humility and people at work (as employees/stakeholders, decision-makers, customers, communicators, creators, individual investors, etc.), in knowledge base, in competition, strategies and operations, in business-society relations and corporate social responsibility. All basic principles of Management 1.0 - rationality, measurement, standardization and universality, specialization, hierarchy, control, predictability, and extrinsic rewards are being questioned and rethinked.

Actually we are facing new management revolution. In the history of management from the ancient times such revolutions were attributed to major qualitative shifts of paradigms and prevailing administrative practices, which eventually have led to significant social transformations, changes in organizations and roles of their members have to be reconsidered and explored. Since the beginning of the 20th century management thinking, ideology and practice have changed dramatically. With Industrial Revolutions 3.0 (and currently with 4.0) for the first time in the human history the management activity has shifted from the real (physical) to virtual world with virtual organizations, jobs, communications, management, leadership, education, new digital thinking and values which really means the new management revolution.

\section{Methodology}

This article generalizes the major ideas and concepts of several influential business thinkers of the 21 st century. The issues and problems for further research which were put forward and are worthy of business discussing and education are presented. The author suggests to start with several notional dichotomies laying in the heart of this discourse which could provide the background for general contemporary management thinking of students. Also the notional conceptual model describing current management revolution is suggested. Each of the notions in the model as well as related topics must be analyzed in details to build the holistic vision of modern management. 


\section{Results and Discussion}

\subsection{Barriers of Changes and New Thinking}

Changes as well as new paradigms usually are initially opposed by many people due to various reasons. New management paradigm is also the case. Such resistance is related to mental models and several types of common barriers.

First barriers are connected with the "Paradigm Effect" (Barker, 1993). People tend to filter out information that doesn't fit their or conventional paradigm. This can block creative solutions to problems and the ability to see the future.

Second barriers emerge when people resist change when they operate within old paradigms. These paradigms establish boundaries and provide the rules for success. But this is an old experience and success with no guaranties and guidelines for the same future achievements (Gharajedaghi, 2006; Rosenzweig, 2007).

Third barriers are related to human relations. The people who create new paradigms (the pioneers) are usually outsiders and by nature contrarians (Barker, 1993; Hamel and Breen, 2007). They are not part of the established paradigm community or mental model.

Forth barriers have individual psychological character: fear of new and unknown, fear of mistakes, standard thinking, behavior, decision making, and interactions, denial of new and different, etc. (O'Connor and McDermott, 1997).

Fifth barriers are related to conventional rational thinking (or mainly left- brain thinking) with desire to split the whole and analyze parts, to analyze linear processes, consequences and effects, to implement clear logical schemes, solutions, etc.

Sixth barriers, are also quite typical since we are trying to solve tasks but not the problems which are often far deeper than it could be seen at the first glance, more complex, or even latent. It is a problem of "seen but not visible". Moreover, sometimes we are solving wrong problems due to the lack of knowledge, skills, abilities or will to reveal and analyze the real ones.

Seventh barriers emerge as a result of lack of complex understanding of human behavior with ignorance of meaningful, moral, emotional, spiritual, and creative side of activity.

All these barriers are interrelated and can be referred to what is called different "mental traps" (Kukla, 2007). Overcoming them means opening a door to "unknown", "new" and "different" which will eventually lead to advantages and success. 


\subsection{Basic Dichotomies in Modern Management}

To understand all current transformations business students, have to start with several notional dichotomies (or dilemmas) which could help them to understand the essence of these shifts and to build the new thinking. In conventional meaning dichotomy is a division or contrast between two things that are represented as being opposed or entirely different. In case of management they coexist in one way or another with dominance of each part either in prevailing ideology or in particular practices and contingencies. Let's address to some of them.

Order vs Chaos is probably the fundamental one which lies in the heart of management despite its different forms. The basic meaning of management is to establish and preserve some kind of order in the system and to avoid disorder. Economics and complexity theory have identified two fundamentally different forms of order-the controlled order on which management by hierarchical control has relied (M1.0) and self-organized spontaneous order (Adam Smith's "invisible hand"), the arranging of activities and resources in a manner that produces desirable results without any direct influence, force, or action by management. In classical M1.0 paradigm chaos is absolute threat, in M2.0 it is essential, acceptable or even sometimes necessary being deliberately designed and somehow controlled in organizations to stimulate creativity and innovations. This shift in new understanding of chaos in management has started in 1980-s (Peters, 1988) and the theory of chaos is developing since we are facing more and more chaotic processes in organizations and in society.

All this lead to increasing complexity which became a keyword at the cutting edge of modern thought. It is a new paradigm of knowing, or, rather, a new way of conceptualizing knowledge. The world increases in complexity, it begins to display new properties that had never existed before. Complexity need knowing and understanding of the whole, it acquires new properties, it is related to spontaneous behavior and self-organization (Tasaka, 1999).

Control vs Freedom is related dichotomy. If you go back 100 years when scientific management was invented the ideology of management was "controlism". Traditional assumptions underlying hierarchical control were following: freedom for employees produce disorder and chaos; control of property and business processes requires control of employees, etc. But such prevalence of control undermine freedom, adaptability, creativity, and engagement. This contradiction is well stated by Richard Florida: "The biggest issue at stake in this emerging age is the ongoing tension between creativity and organization" (Florida, 2004).

Thus the freedom-based principles on the other hand, produce an environment within which management can take advantage of "self-organized spontaneous order" by earning employee commitment to the vision for success, aligning their interests with those of the business, harmonizing their needs with those of the business, and giving them primary 
responsibility for organizational control and accountability. Individuals who share the intrinsic satisfactions and financial rewards of business success are self-motivated to do their best to help the enterprise succeed, to develop themselves, to self-control and selfcoordinate their activities guided by the many indirect influences within their freedombased culture. Different dimensions of freedom add special business value inside organizations: freedom to develop; freedom to make mistakes and to fail; freedom to question and to investigate; free of information; freedom to decide and to act; freedom from boundaries; freedom from arbitrary limitations such as work hours, location, dress, etc. (Nobles and Staley, 2010).

Linearity vs non linearity is the next dichotomy related to the first one. Actually more chaotic world due to its complexity is nonlinear by nature with no strict causality, nonlinear and rather cyclical continuity, with uncertainty and contingencies ("The Black Swans" (Taleb, 2007), with no strict predictability, and with variety of unexpected and difficult for evaluation consequences. The examples of nonlinearity in management are numerous. In marketing it is consumer behavior (De Langhe et al, 2017). In corporate governance practices more rules, norms, procedures, etc. doesn't necessary mean better, effective or ethical conduct and performance. A business itself is more than just a sum of individual stakeholders but their complex integration, interrelations and interdependence which lead to new synergy. The dominant linear method was the PDCA - Plan Do Check Act. Then, the fixed stages disappeared; the imbalance was permanent, hatching the management of the complexity mitigating the linear approaches (Farooq, 2017). The uni-directional value chain - the very core of 20th Century management thinking-is now a problem, not a solution (Denning, 2013).

Instead of working in linear mode, agile management is established in iterative experiential mode (Apello, 2011; Denning, 2018). In a nonlinear world only different and nonlinear ideas (out of incremental logic) and radical innovations will create wealth, complexly new market space, escape the ruthless hyper competition, past experience and imagine entirely novel breakthrough solutions (Hamel, 2012).

Stability vs change. Stability in the rapid modern world is a big illusion and often even threat. Actually we are facing the ongoing changes everywhere. As it is being stated, probably changes are the only constant in development but their vector, character, content, and pace have changed (Hamel, 2012). Stability, at least in our perceptions, is also often referred to order, constancy, and predictability. But, as it is suggested by Nassim Taleb, it is the contrast of "fragile" and "antifragile" where the first one is outwardly stable, controlled and sustainable, but internally very vulnerable to different external impacts, shocks, uncertainty, and stressors and thus very fragile (Taleb, 2012). Antifragile is about changes, it suggests solutions how to gain from disorder, instability and changes to survive and flourish.

Rational vs Irrational. As we have stated above pure rationality of Management 1.0 is currently being questioned by several influential thinkers. Dan Ariely refutes the common assumption that we behave in fundamentally rational ways. He examines some of the 
positive effects of irrationality on our lives, decisions, and work (Ariely, 2008; Ariely, 2010). A man is no more just an "economic man" (A. Smith) - we are also social, emotional, spiritual persons. We are both left- and right-brain thinkers and sometimes it's difficult to say which side is dominant in our decision making, choices, expectations, perceptions, preferences, and behavior (Pink, 2006). We have multiple intelligence besides just the rational one (Gardner, 1983). Later on this concept was extended by several other researchers who suggested emotional, spiritual, creative, design, change intelligence needed for leaders and managers to be really effective dealing with today's people (Akerlof and Shiller, 2009; Goleman, 1996; Zohar and Marshall, 2000).

Egoism vs Altruism (or Money vs Moral). These are the basic ethical dilemmas in business because they address the meaning of business purpose. Today it is quite obvious for many thinkers that self-interest, money and shareholder's profit maximization are not the only purpose and measure of business. Delivering goods and services, and making money are the finite goals. With egocentricity vision any means justifying the goals with unethical behavior often became "normalized", and it's a big danger for any society. But management in the 21st century must be grounded on different ethical system based on value creation for all stakeholders, it is about the infinite goal of delivering such value to society, building the "new normality" and new moral thinking. Hence this goal is inherently sustainable (Denning, 2010; Mackey and Sisodia, 2014). Such multiple value has different perceptions - physical, economic, social, cultural, intellectual, emotional, environmental, spiritual. Humility encourages giving credit to others, it creates a mindset of serving the needs of associates, it reinforces the need for continual improvement. A vision for success provides what Deming called "constancy of purpose," a critical element missing from many hierarchically controlled companies. It provides the need to selfcontrol and self-coordinate different activities, and focuses attention outward on customers and the marketplace instead of upward toward management (Nobles and Staley, 2010).

All these issues became even more evident and relevant nowadays during the Covid-19 pandemic when we are facing the new reality and the new risks and when we have to rethink much of our traditional approaches and practices.

\subsection{The Conceptual model for New Management Thinking and Education}

As we have stressed above, the concept of new management revolution was discussed by several influential thinkers (Drucker, 2001; Kemp et al, 2013). Therefore, the following conceptual model for further business studies could be suggested the and it is called the REVOLUTION (Kuzin, 2014). This is an open model which means that each letter in this word is related to a number of definite notions which are widely used and analyzed in business literature and all of them are interrelated. They must be addressed in more detail if we would like to build the holistic view of modern management. 
Reality. To develop the new management thinking first of all we have to understand, properly describe and analyze the reality and contemporary business environment. But, unfortunately very often we don't really understand the world we live in. Then how could we effectively manage? Our limited knowledge and understanding of many contemporary complexities, events, interdependencies and their consequences, very often doesn't allow effective dealing with this uncertain, unpredictable and rather risky reality. To make sense of this reality, we rely on assumptions, on stable mental models, on what Luc de Brabandere and Alan Iny call "boxes" (De Brabandere and Iny, 2012). If we are thinking within the old "boxes" usually we simplify the reality. When people think in "new boxes", they learn how to ask the right questions in order to open up the most promising doors to creativity, innovation, and opportunity. Such type of thinking suggests to doubt everything, to explore options, to generate many new and exciting ideas, to converge, and to reevaluate everything. Thus our new plans destroy old principles and structures and create new reality and it is very energy intensive process.

Effectiveness/efficiency \& Ethics. Therefore, we have to reconsider the traditional meaning and criteria of effectiveness in terms of corporate purpose, long-term goals and returns, agility, strategy implementation, competitiveness, sustainability, as well as different technological, production, social and ecological impacts of business activity. Quite often ineffectiveness is related to standard way of thinking and behavior, with psychological fare of new and different, with inertia and searching for stability is which is actually often an illusion in a very dynamic and changing world.

Rethinking of effectiveness criteria put forward the issue of measurable and nonmeasurable (less measurable) in management and it also is related to management and leadership goals within different paradigms and transformations. If we state this goals as amplification and then aggregation of human efforts by providing them with new values, appropriate tools, incentives, working conditions, by their involvement in different processes, then the whole set of criteria is changing.

The other side is business ethics which is still a big question mark. Probably one of the major problems of contemporary society is normalization of unethical behavior and the necessity to build new normality with lower selfishness, unfairness, corruption, fraud, greed, etc. and with higher morale, responsibility, consciousness, and the sense of social purpose.

Value \& Variety of Values. The previous one is connected with new set of meanings and values. Both of them determine the goals and objectives and respectfully the ways of behavior. The perception of value and values has changed especially when we are more sinking into virtual reality. A shift in values from a preoccupation with efficiency to a broader set of values ("doing right things") will change the vision and foster continuous innovation. Conscious management focuses on shared human values, not just shared economic value. The last one lacks the intangible but critical emotional and spiritual motivators that give extraordinary power. "Management-by-values" which is comparatively new concept of the 21 st century has supplemented and partly supplant the 
previous concepts - "management-by-instructions" (MBI) and "management-byobjectives" (MBO) (Dolan and Garcia, 2006). Another previous concept "value-basedmanagement" (VBM) on one hand side deals more with the shift in the financial thinking, analysis and business evaluation, and on the other side with strategic issues and corporate governance in terms of stakeholder's approach.

Obligations. The changing perception of business purpose extend obligations of managers and leaders with more ethical and social focus - both inside and outside the organizations. These obligations presume corporate social responsibility (CSR) which became the mainstream in contemporary corporate strategic activity (Smith and Lenssen, 2009). But "conscious capitalism", in Mackey \& Sisodia (2014) view, is not just CSR. A good business doesn't need to do anything special to be socially responsible. When it creates value for its major stakeholders, it is acting in a socially responsible way.

Leadership. At least over the last 70 years leadership is the top issue in management studies, discourse and practice. But still the transformation of leaders' knowledge, competencies, roles, behavior and responsibility are addressed by many authors and new vision of leadership is presented. Such new tendencies in leadership like intellectual and emotional, ethical and virtuous, virtual and digital are more and more explored. Leadership mindset change the pattern of control. Leadership design is no more about just skills and style but more about meanings and values, character and consciousness, emergence and empowerment in organizations. It is about shared traits as trust, accountability, transparency, integrity, loyalty, fairness, personal development, care, etc. (Denning, 2018). Leading in today's knowledge-driven and highly competitive business environment requires practical experience and skills to motivate followers to achieve organizational objectives and create value added in the organizations. It is new "level three leadership" focusing on what managers can do to influence the thinking and feeling of others (3d level) -rather than focusing on changing behavior (1st level) and conscious thinking (2nd level) (Clawson, 2012; Dike et al, 2015).

Uncertainty \& Unpredictability became the core notions in contemporary business language when we are facing the reality with market, financial, information, professional, behavioral, regulatory, environmental and other non-simplicity and complexity. Nassim Taleb is one of those who has fundamentally addressed this issue and various aspects of managing risk and uncertainty in his great cycle of works named Incerto (2001-2018). The humans are hardwired to learn specifics when they should be focused on generalities. We concentrate on things we already know and very often fail to take into consideration what we don't know, don't see or don't understand. We are, therefore, try to simplify and categorize everything, and unable to truly estimate threats and opportunities. Thus we restrict our thinking. Taleb stands uncertainty on its head, making it desirable, even necessary, and proposes that things be built in an antifragile manner.

Trust is currently also one of the core values, the focus of research and discussions in business, management, and society. After the global 2008 crisis this issue became even 
more addressed not just from the social or ethical sides as core framework of developed society (Fukuyama, 1995) but also as a complex contemporary problem of distrust due to the lack of transparency, manipulations, corruption and other unethical behavior, unfairness, violations of obligations, etc. Besides being the fundamental value creating the social capital, trust is the economic value - "hidden tax" and costs, dividend and multiplier, factor of investment attractiveness and changes, strategic asset and force of knowledge (De Brabandere and Iny, 2012; Lesser and Prusak, 2004). It is also one of the major attributes of modern global leaders capable to build such trust in their organizations and worldwide. We could also add here the well-known R. Florida's 3T creativity concept (talents, tolerance, technology) (Florida, 2004) as well as transparency.

Intelligence \& Innovations. Both notions are quite obvious if we are talking about knowledge and digital economy, creativity, radical technological and commercial breakthroughs, new leadership and management, excellence and superiority, competitiveness and future economic success in the digital age (Andersson et al, 2018; Hamel, 2000; Hamel, 2012). They are in the core list of contemporary business values and are symbols of M3.0 revolution.

Organizations have transformed due to the changes mentioned above. They need to be more open and transparent, more collaborative and participative, more agile, team-based and client-oriented, more networking and less hierarchical, bureaucratic, and conservative. This will bring changes in leadership and management, in the place of people in organizations, in the way they relate to one another, how they communicate as well as changes in their skills, competencies, and careers. It will change the purpose of organizations, their contribution to creation of wealth, their forms of "coopetition" in new ecosystems and regulation of activities, etc. (Apello, 2011; Denning, 2018; Laloux, 2014).

Needs. Finally, we have to understand various new human needs; interests, needs, and expectations of different stakeholders; we have to address them and respond in a more efficient and effective ways. We need changes and new radical innovations, new leaders with new capabilities and vision, we need healthy organizations, interesting and creative jobs, we need better and more just, transparent, safe and healthy world, eventually, we need more humility in our relationships. Thus again we have to rethink the reality and the ways of doing business, managing and living.

\section{Conclusions}

The evolution of management thinking is ongoing process and it takes time and it can't happen overnight. It is related to contradictions, misunderstanding, dissonance, and "mental traps". But the future managers of the 21st century must overcome all these difficulties to be more effective in the coming digital age. The suggested study model obviously doesn't pretend to be neither complete, nor sufficient. It could be supplemented with other related notions and topics. But anyway, in my view, it could provide some grounds for new management thinking. 
Besides new management thinking which is the basis of activity modern business students will need plenty of practical exercises in using the 21st century knowledge and skills such as critical thinking and problem solving, digital communication and selfdevelopment skills, etc. (Trilling and Fadel, 2009).

The basic ideas and concepts addressed in this article were included and extended in the text book "Contemporary Management Concepts: The Paradigms Shift" (Kuzin, 2021) suggested as the reading for master degree students.

\section{References}

Akerlof, G., and Shiller, R. (2009) Animal Spirits. How Human Psychology Drives the Economy, and Why It Matters for Global Capitalism. Princeton and Oxford: Princeton University Press.

Andersson, P., Movin, S., Mähring, M., Teigland, R., and Wennberg, K. (2018) Managing Digital Transformation. Stockholm School of Economics Institute for Research (SIR): BrandFactory, Göteborg.

Apello, J. (2011). Management 3.0. Leading Agile Developers, Developing Agile Leaders. New Jersey: Addison-Wesley.

Ariely, D. (2008). Predictably Irrational. N.Y.: Harper Collins.

Ariely, D. (2010). The Upside of Irrationality. N.Y.: Harper Collins.

Barker, J.A. (1993). Paradigms: The Business of Discovering the Future. Harper Business.

Clawson, J. G. (2012). Level Three Leadership: Getting Below the Surface. Prentice Hall.

De Brabandere, L., and Iny, A. (2012). Thinking in New Boxes. A New Paradigm for Business Creativity. The Boston Consulting Group, Random House.

De Langhe, B., Puntoni, S., and Larrick, R. (2017). Linear Thinking in Non Linear World. Harvard Business Review, May-June 2017.

Denning, St. (2010). The Leader's Guide to Radical Management. Re-inventing the Workplace for the 21st Century. Jossey-Bass.

Denning, St. (2013). The Management Revolution That's Already Happening. Forbes, May 30, 2013.

Denning, St. (2018). The Age of Agile: How Smart Companies Are Transforming the Way Work Gets Done. Amakom

Dike, V.E., Odiwe, K., and Ehujor, D.M. (2015). Leadership and Management in the 21st Century Organizations: A Practical Approach. World Journal of Social Science Research, 2 (2), 139-159.

Dolan, S.L., and Garcia, S. (2006). Managing by Values. A Corporate Guide to Living, Being Alive, and Making Living in the 21 st Century. London: Pretext.

Drucker, P. F. (1998). Management's New Paradigms. Forbes, October 5, 1998.

Drucker, P. F. (2001). Management Challenges for the 21st Century. N.Y: Harper Business.

Gharajedaghi, J. (2006). Systems Thinking: Managing Chaos and Complexity. Second Edition. Elsevier. 
Gardner, H. (1983). Frames of Mind: The Theory of Multiple Intelligences. N.Y.: Basic Books.

Goleman, D. (1996). Emotional Intelligence. Why It Can Matter More Than IQ. Bantam Books.

Farooq, U. (2017). What's New in Business Management at the Beginning of 2018. Human Resource Management, November 29. 2017.

Florida, R. (2004). The Rise of the Creative Class. N.Y.: Basic Books.

Friedman, T. L. (2007). The world is flat 3.0: A brief history of the twenty-first century. N.Y.: Picador.

Fukuyama, F. (1995). Trust: The Social Virtues and the Creation of Prosperity. Free Press.

Hamel, G. (2000). Leading the Revolution. HBR Press.

Hamel, G., and Breen, B. (2007). The Future of Management. Harvard Business School Press, Boston.

Hamel, G. (2012). What matters now: How to win in a world of relentless change, ferocious competition, and unstoppable innovation. John Wiley \& Sons.

Kane, G.C., Palmer, D., Phillips, A.N., Kiron, D., and Buckley, N. (2018). Coming of Age Digitally. MIT Sloan Management Review and Deloitte Insights, June, 2018.

Kemp, J., Witzel, M., and Schotter, A. (2013). Management Frameworks: Aligning Strategic Thinking and Execution. Routledge.

Kukla, A. (2007). Mental Traps. The Overthinker's Guide to Happier Life. Anchor Canada.

Kuzin, D. (2014). Different Management. The Metaphysics of Modern Management. International University in Moscow (in Russian)

Kuzin, D. (2021). Contemporary management concepts: a paradigm shift (textbook). Moscow: Knorus (in Russian).

Laloux, F. (2014). Reinventing Organizations. A Guide to Creating Organizations Inspired by the Next Stage of Human Consciousness. Nelson Parker.

Lesser, E., \& Prusak, L.(eds) (2004). Creating value with knowledge: Insights from the IBM Institute for Business Value. N.Y.: Oxford University Press.

Mackey, J. and Sisodia, R. (2014). Conscious Capitalism: Liberating the Heroic Spirit of Business. Harvard Business Review Press.

Nobles, B., and Staley, P. (2010) Freedom-based Management, http://www.42projects.org/docs/FreedomBasedManagement.pdf

O'Connor, G., McDermott, I. (1997). The Art of Systems Thinking. Essential Skills for Creativity and Problem Solving. Thorsons.

Oswald, A., and Müller, W. (eds). (2017). Management 4.0. Handbook for Agile Practices. Kindle Edition.

Pink, D.H. (2006). A Whole New Mind: Why Right-brainers will Rule the Future. Penguin.

Peters, T. (1988). Thriving on Chaos: Handbook for a Management Revolution. Harper Perennial.

Prensky, M. (2001). Digital natives, digital immigrants. On the Horizon, 9(5), 1-6, https://doi.org/10.1108/10748120110424816

Rosenzweig, P. (2007). The Halo Effect: ....and the Eight Other Business Delusions That Deceive Managers. Free Press, Simon\&Schuster, Inc. 


\section{Geduweb}

Revista de Tecnología de Información y Comunicación en Educación • Volumen 15, № 2. Mayo-agosto 2021

Schwab, K. (2016). The Fourth Industrial Revolution. World Economic Forum.

Smith, N.G., and Lenssen G.(eds). (2009). Mainstreaming Corporate Responsibility. Glasgow: Wiley.

Taleb, N. (2007). The Black Swan: The Impact of the Highly Improbable. N.Y.: Random House and Penguin Books.

Taleb, N. (2012). Antifragile: Things That Gain from Disorder. N.Y.: Random House.

Tasaka, H. (1999). Twenty-first-century Management and the Complexity Paradigm. Emergence, 1(4), 115-123.

Trilling, B., and Fadel, C. (2009). 21st Century Skills: Learning for Life in Our Times. San Francisco: John Wiley \& Sons, Inc.

Vaganova, O., Livshits, Y., Aleshugina, E., Smirnova, Z., \& Kutepova, L. (2019). Experience in developing electronic glossary in a higher education institution. Amazonia Investiga, 8(22), 247-253. Retrieved from https://amazoniainvestiga.info/index.php/amazonia/article/view/421

Zohar, D., and Marshall, I. (2000). Spiritual Intelligence. The Ultimate Intelligence. London: Bloomsbury. 